Mem. Inst. Oswaldo Cruz, Rio de Janeiro, Vol. 78(2):135-146, abr./jun. 1983

\title{
INTERACTIONS BETWEEN LEISHMANIA MEXICANA MEXICANA PROMASTIGOTES AND AMASTIGOTES AND MURINE PERITONEAL MACROPHAGES IN VITRO
}

\author{
GABRIEL GRIMALDI JR. \\ SUZANA CÔRTE-REAL \\ ROSA T. DE PINHO \\ PAMELA L. MORIEARTY
}

Unstimulated adherent mouse peritoneal cells were cultured in vitro and infected with equal numbers of a single strain of Leishmania m. mexicana amastigotes $(A M)$, virulent promastigotes (VP), avirulent promastigotes $(A V P)$ and fixed promastigotes $(F P)$. Duplicate May-Grünwald-Giemsa stained coverslips were examined at time intervals up to 13 days. By $3 \mathrm{hr}$ post infection, the number of macrophages containing parasites varied between $60.5 \%(V P)$ and $84 \%$ (AM) for macrophages exposed to living parasites, compared to $6.5 \%$ for macrophages exposed for FP. However, variable numbers of parasites showed degenerative changes by $3 \mathrm{hr}$, and the number of macrophages containing morphologically intact parasites varied significantly between cells infected with $A M(84 \%)$ and those infected with VP (42\%) or AVP $(40 \%)$. The mean number of intact parasites/macrophage also differed significantly between AM-infected cells and living or fixed promastigotes-infected cells. Quantitation of intact and degenerated parasites indicated parasite multiplication, as well as destruction, in VP-infected cells and parasite survival and multiplication in AM-infected monolayers; in contrast no evidence of parasite multiplication was seen in AVP-infected cells. Changes in the monolayer itself /cell loss and macrophage vacuolization) were also evaluated. These results suggest that crucial events determining the outcome of infection occur in the host-parasite relationship during the first 24 hours of infection. These events are apparently influenced not only by parasite or host strain but by environmentally induced variations within a given strain.

Protozoa of the Leishmania genus are obligate intracellular parasites of the mononuclear phagocytes of their mammalian hosts. Macrophage cultures in vitro have therefore been used to study details of the host-parasite relationship under controlled conditions. The fate of Leishmania within the macrophage seems to depend not only on the species, strain, and stage of the parasite but also on genetically determined characteristics and state of maturation or stimulation of the host cell (Behin et al. 1977; Behin, Mauel \&

This study was supported in part by grants from the Brazilian National Council of Scientific Development and Technology (CNPq) under contract number $2222.8 .067 / 80$.

Instituto Oswaldo Cruz - Caixa Postal 926 - 20000 Rio de Janeiro, RJ. - Brazil.

Received for publication July $7^{\text {th }}$ and accepted August $4^{\text {th }}, 1982$. 
Sordat 1979; Handman, Ceredig \& Mitchell 1979; Mauel 1979; Haidaris \& Bonventure 1981).

Promastigotes are more sensitive than amastigotes to intracellular destruction, even in normal or resident macrophages (Lewis \& Peters 1977). Some observations also indicate that promastigotes are susceptible to reactive oxygen products. This form of $L$. donovani and $L$. tropica readily triggers the oxidative burst of resident mouse peritoneal macrophages, resulting in production of toxic $\mathrm{H}_{2} \mathrm{O}_{2}$; most intracellular parasites are thus killed within $18 \mathrm{hr}$ of interiorization (Murray 1981). Susceptibility of the amastigote form of $L$. enriettii to oxygen intermediates produced by activated mouse macrophages has been reported (Buchmüller \& Mauel 1981).

Long term in vitro culture of promastigotes results in loss of virulence of the parasite, as determined by infectivity in vivo for laboratory hosts (Grimaldi, Momem, Soares \& Moriearty 1982). Ebert, Buse \& Mühlpfordt (1979) report significant differences in the number of parasites taken up in vitro by hamster peritoneal macrophages infected with avirulent and virulent promastigotes of $L$. donovani, followed by multiplication of virulent but not avirulent parasites. Kutish \& Janovy (1981), infecting hamster peritoneal macrophages with promastigotes of two $L$. donovani strains, also demonstrated that avirulent forms were rapidly destroyed while virulent ones multiplied. No studies to date have compared the outcome in vitro of infection with avirulent promastigotes, virulent promastigotes and amastigotes of the same parasite strain within the same host cell system.

The purpose of the present investigation was to analyze in vitro the infectivity and intracellular fate of three different samples of a single strain of L. mexicana mexicana during culture periods up to 13 days. In this system there was no difference in infectivity of avirulent and virulent promastigotes, but the former were destroyed much more rapidly that the latter. Amastigotes were highly infective and apparently totally resistant to destruction by the host cell.

\section{MATERIALS AND METHODS}

Parasite. The "strain 5" of Leishmania mexicana mexicana used in all experiments was originally supplied by Dr. Z. BRENNER, René Rachou Research Center, FIOCRUZ, Belo Horizonte (Brazil). It was maintained by serial subcutaneous passage in outbred albino Swiss-Webster mice. Samples of this strain 5 from the following origins were prepared for infection of macrophage cultures: amastigotes isolated from chronic cutaneous lesions in albino mice (AM), promastigotes obtained by transformation of amastigotes and maintained in vitro for one week (VP or virulent promastigotes; capacity to induce lesions in mice); promastigotes obtained by transformation of amastigotes and maintained by serial passage in vitro for two years (AVP or avirulent promastigotes; reduced capacity to induce lesions in mice). The virulence of promastigotes was tested by their infectivity in outbred albino Swiss-Webster mice, described elsewhere (Grimaldi et al. 1982). To evaluate the reaction to dead rather than living parasites, macrophages were exposed to fixed promastigotes (FP) (VP, fixed in $2.5 \%$ gluteraldehyde in cocadylate buffer $0.1 \mathrm{M}, \mathrm{pH} 7.4$ ).

Sample preparation. Amastigotes were obtained by a modification of the method of Berman, Dwyer \& Wyler (1979), described elsewhere (Grimaldi et al. 1982). Promastigotes were obtained by culturing fragments from cutaneous lesions from albino mice in NNN blood agar medium with an overlay of Hanks' balanced salt solution (HBSS) containing antibiotics, then subculturing in modified LIT liquid medium (Gutteridge, Knowler \& Coombes 1969). In the preparation of samples, the parasites (amastigotes in suspension obtained by previous method, and promastigotes in late log phase of growth in culture) were harvested by centrifugation $\left(1,500,10 \mathrm{~min}, 4^{\circ} \mathrm{C}\right)$, washed in tissue culture 
medium 199 containing $20 \%$ heat inactived foetal bovine serum (M $199+20 \%$ FBS), and adjusted to the desired concentration.

Macrophage cultures. Macrophages were obtained from the unstimulated peritoneum of outbred albino Swiss-Webster mice. The animals were killed by dislocation of the neck and each inoculated intraperitoneally with $3 \mathrm{ml} \mathrm{M} 199+20 \%$ FBS containing $5 \mathrm{U}$ heparin $/ \mathrm{ml}$ and antibiotics $(200 \mathrm{U} / \mathrm{ml}$ Penicilin, $200 \mu \mathrm{g} / \mathrm{ml}$ Streptomycin). Exudates collected from several mice were pooled, samples were coun'ed in an improved Neubauer hemocy tometer, and the cell density was adjusted to $2 \times 10^{6} / \mathrm{ml} ; 1.5 \mathrm{ml}$ of cell suspension was added to Leighton tubes containing $10 \times 35 \mathrm{~mm}$ coverslips. Cultures were incubated at $37^{\circ} \mathrm{C}$ with $5 \% \mathrm{CO}_{2}$ in air to allow the macrophages to settle on the coverslips. After $4 \mathrm{~h}$ the non-adherent cells were washed away and fresh medium was added to the tubes containing adherent cells.

Leishmania-macrophage interaction. The prepared cells, after rinsing with $\mathrm{M} 199+$ $+20 \%$ FBS, were challenged with the different Leishmania populations (AM, VP, AVP and FP) $24 \mathrm{~h}$ after incubation. Leishmania populations were suspended in M $199+20 \%$ FBS and added to glass adherent cells at a ratio of $1 / 5$ (peritoneal cell: parasites). The parasites were allowed to remain at $37^{\circ} \mathrm{C}$ for $3 \mathrm{~h}$, and then the infected macrophages were washed thoroughly to remove unattached extracellular or non-phagocytized parasites. Medium was changed on days $3,5,7,9$ and 11 of culture. At various time intervals ( $3 \mathrm{hr}$, $1,2,3,6,8,10$ and 13 days) duplicate coverslips were fixed with absolute methanol for 1 min and stained with May-Grünwald-Giemsa. In a total of 200 macrophages the number of infected cells and the morphology of parasite elements were recorded! as follows: intact parasites (with well preserved membrane, nucleus, and kinetoplast); degenerated parasites (with no individualized structures, forming a compact and dense or a granulated well delimited mass) and residual bodies (compact masses staining similarly to degenerated parasites, but smaller in diameter and not confined within clear limits). The mean number of intact parasites/macrophage (evaluated in a total of 100 infected cells) and changes in the monolayer itself (cell loss, macrophage vacuolization), were also evaluated. To estimate cell loss from monolayer at each time period, the mean number of macrophages/field was determined in five $40 \mathrm{x}$ fields whose coordinates were preselected on the calibrated microscope stage. Total numbers of cells and per cent of cells containing intact parasites at later time periods were expressed as a per cent of cells present at $3 \mathrm{~h}$.

Statistical analysis. Differences in per cent of infected cells were evaluated by the Chi-square test with one degree of freedom. Mean numbers of intact parasites/macrophage were compared by Student's t-test.

\section{RESULTS}

Cell loss from monolayers. Monolayers infected with fixed promastigotes showed little loss during the first 6 days (Fig. 4), with preservation of approximately $35 \%$ on the 13 th day. In contrast, monolayers infected with living organisms lost cells rapidly during the first $24-48 \mathrm{hr}$ of culture, but then stabilized during the remaining observation period (Fig. 1 A, 2A, 3). Loss was apparently not proportional to intensity of infection of the monolayer. Calculations of percent of cells with intact parasites were corrected for this loss to aid in distinction between parasite multiplication and possible transfer of amastigotes from one cell to another.

Vacuolization of macrophages was related to parasite preservation, infection intensity and duration of parasitization. Thus, 25 per cent of AM-infected macrophages showed vacuolization at $24 \mathrm{hr}$, rising to 83 per cent at 3 days and 97 per cent at 6 days. Twenty-one per cent of VP-infected cells showed vacuolization at $24 \mathrm{hr}$, increasing slowly to 31 per cent at 3 days and $70 \%$ at 6 days. In contrast, 26 per cent of AVP-infected cells 
had small vacuoles at $24 \mathrm{hr}$, but vacuolization was not seen at later times in spite of the continued presence of parasite remains within the cells. Similarly, vacuolization was not observed in cells containing fixed parasites.

Parasite-host cell infection ratio. At a ratio of 5 parasites per peritoneal cell (ie $\simeq 10$ parasites per macrophage) the number of cell containing parasites at $3 \mathrm{~h}$ ranged from 60.5 per cent (VP) to 84 per cent (AM) for macrophages exposed to living parasites, compared to 6.5 per cent for macrophages exposed to FP(Figs. 1 B, 2 B, 3,4). However, variable numbers of parasites showed degenerative changes by $3 \mathrm{hr}$, and the number of macrophages containing morphologically intact parasites varied significantly between cells infected with AM (84\%) (Fig. 3) and those infected with VP (42\%) (Fig. 1A) or AVP $(40 \%)$ (Fig. $2 \mathrm{~A})\left(\mathrm{x}^{2}=75.6, \mathrm{P}<0.001\right)$. The mean number of intact parasites/macrophage also differed significantly $(\mathrm{t}=15.7, \mathrm{P}<0.001)$ between AM-infected cells $(\overline{\mathrm{x}}=17.6 \pm 5.9)$ and promastigote-infected cells (VP: $\overline{\mathrm{x}}=5.3 \pm 3.0$; AVP: $\overline{\mathrm{x}}=3.4 \pm 2.4$ ). The mean number of $\mathrm{FP} / \mathrm{macrophage}$ was $1.4 \pm 0.8$.

Parasite multiplication and destruction. Since the total parasite population at any time would result from the combined effects of parasite multiplication and destruction and since possible transfer of amastigotes from one cell to another would influence quantitation, an attempt was made to consider all these factors in analyses of the course of infection.

Thus, while the number of VP-infected cells containing intact amastigotes remained stable between 3 and 8 days (Fig. 1B), the mean number of parasites rose during this period from 4.3 to $6.5 /$ cell, suggesting multiplication (Fig. 1A). Similarly, the increase between 3 and 6 days in the total amastigote population of AM-infected cells could not be explained by transfer from one cell to another (Fig. 3). In contrast, there was no evidence of parasite multiplication in AVP-infected cells (Fig. 2A).

Parasite destruction occurred rapidly in AVP-infected cells; by $3 \mathrm{hr}$ half of the cells which had ingested parasites contained degenerated forms. At $24 \mathrm{hr}$, parasite destruction was marked (Fig. 5a). However, rare cells containing only 1.4 intact amastigotes were seen up to 10 days of infection (Fig. 2B). Destruction occurred more slowly in VP-infected cells (Fig. 1B), but eventually the number of cells containing only intact parasites fell, while the number containing only residual bodies rose progressively. At intermediate time periods ( $2-8$ days) many cells contained both intact parasites and residual bodies (Fig. $5 \mathrm{~b}$ ). In AM-infected monolayers there was no evidence of intracellular parasite destruction at any time. Despite the intensity of infection, all intracellular amastigotes showed normal morphology up to 13 days (Fig. 5c).

Fixed parasites remained either outside and adherent to the host cell membrane, or within host cells during the entire observation period. Though destruction did not occur, the parasites became denser and more compact with time. The morphology of these forms was different from that of residual bodies observed after infection with live promastigotes. The absence of such residual bodies up to 13 days, when some loss of host cells had occurred, suggests that residual bodies do not represent host cell debris.

These studies were a repetition of experiments with different preparations of parasites and host cells, with observation periods up to 10 days. Results were similar in the two sets of experiments in terms of intensities of infection and cell loss from monolayers. However, simple Giemsa staining, used in the first trial, did not result in sufficient preservation of detail to permit quantitative analysis of parasite degeneration. Use of the May-Grünwald-Giemsa was found to be critical in this respect. 


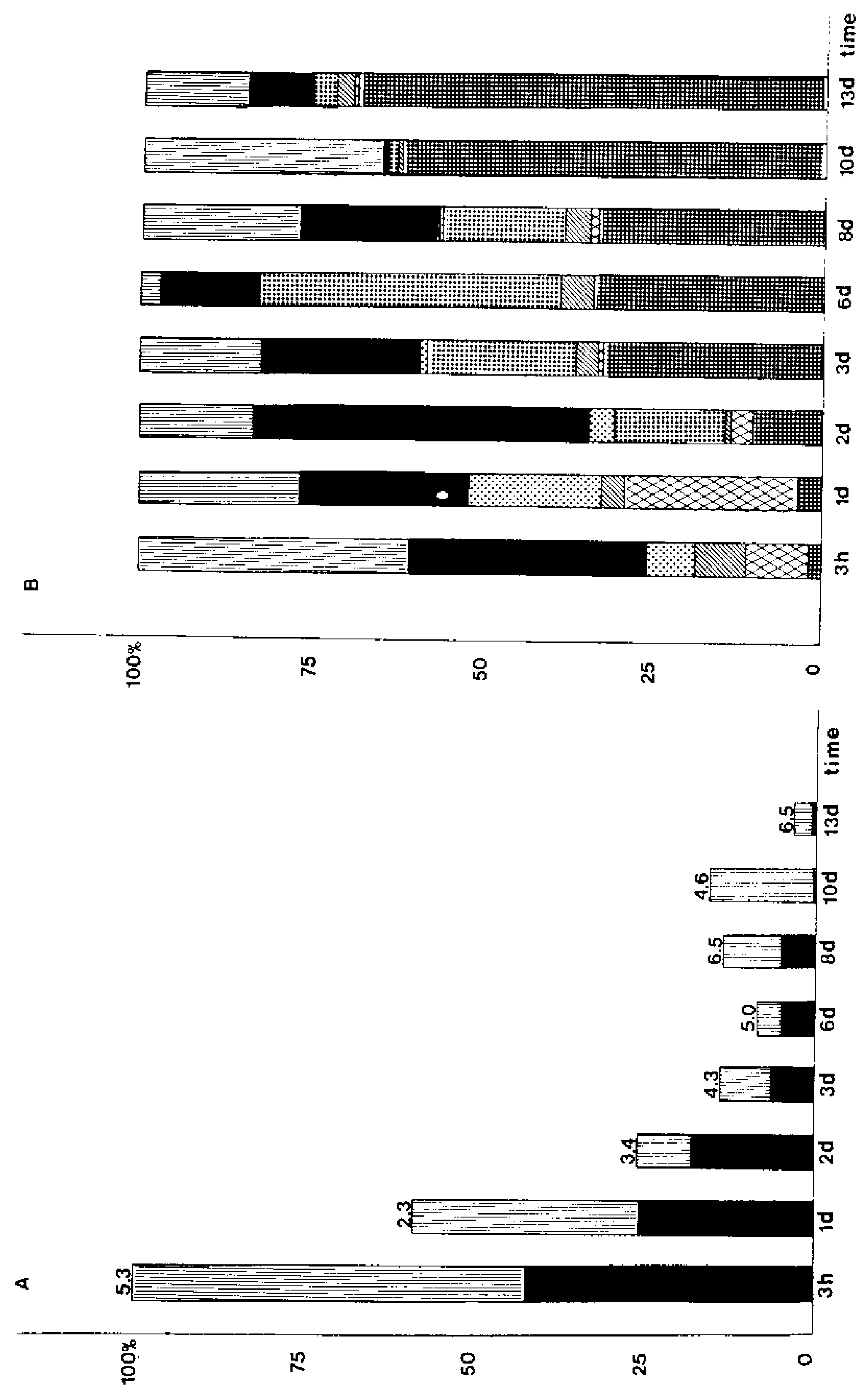

Fig. 1 - In vitro macrophage infection with virulent promastigote

A. Percent of cells with intact parasites/total cells (corrected to 100 cells at 3 hours). The number above each column is the mean number of intact parasites per cell. Macrophages containing $\square$ no parasites; $\boldsymbol{D}$ intact parasites.

B. Relative destribution of parasitic elements per 200 macrophages. Macrophages containing (from the top of the column) no parasites; intact parasites; intact parasites + residual bodies; degenerated parasites; degenera ted parasites + residual bodies; residual bodies. 


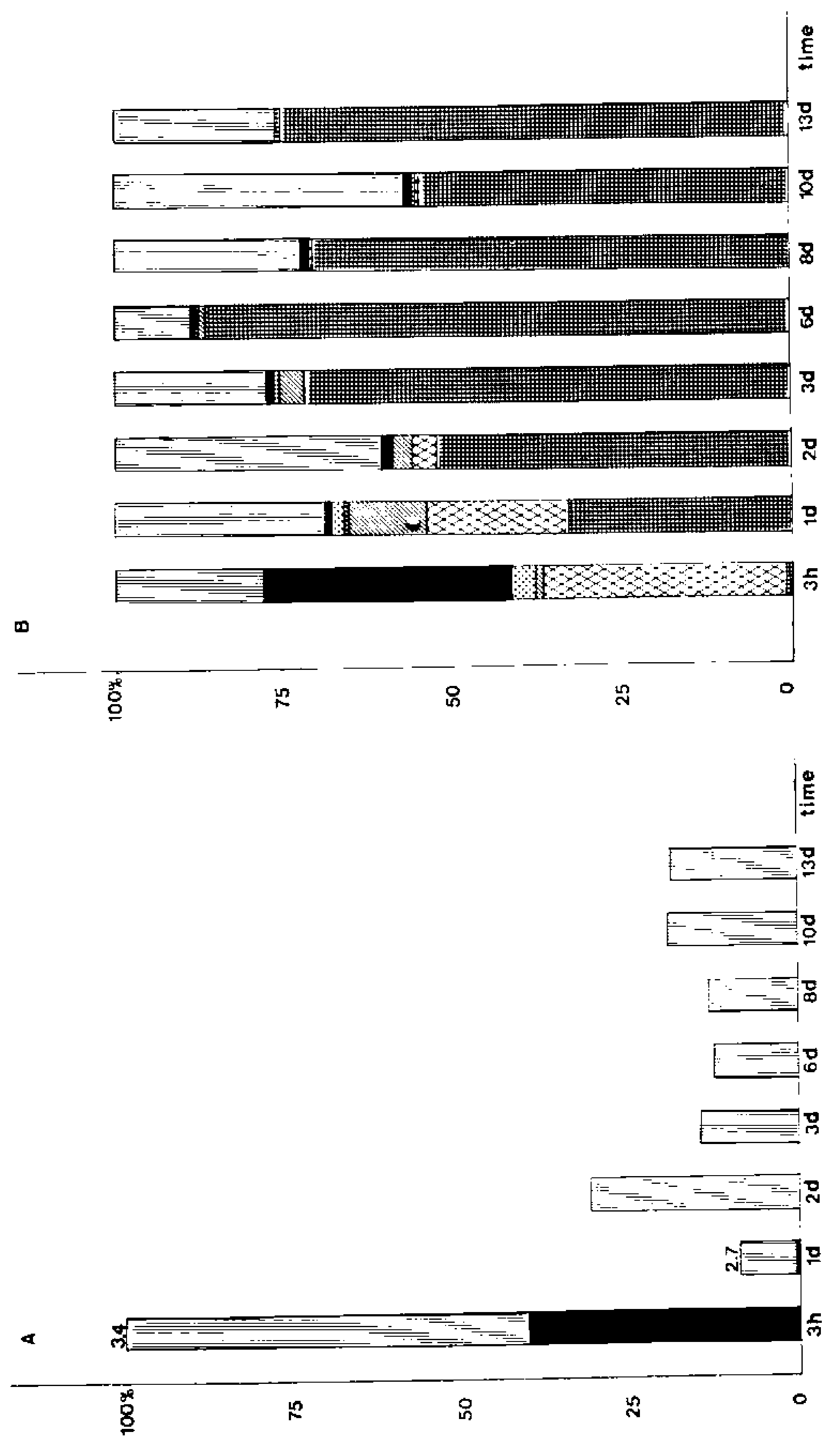

Fig. 2 - In vitro macrophage infection with avirulent promastigote

A. Percent of cells with intact parasites/total cells (corrected to 100 cells at 3 hours). The number above each column is the mean number of intact parasites per cell. Macrophages containing no parasites; $\boldsymbol{\square}$ intact parasites.

B. Relative distribution of parasitic elements per 200 macrophages. Macrophages containing (from the top of the column) no parasites; intact parasites; intact + degenerated parasites; intact parasites + residual bodies; degenerated parasites; degenerated parasites + residual bodies; residual bodies. 


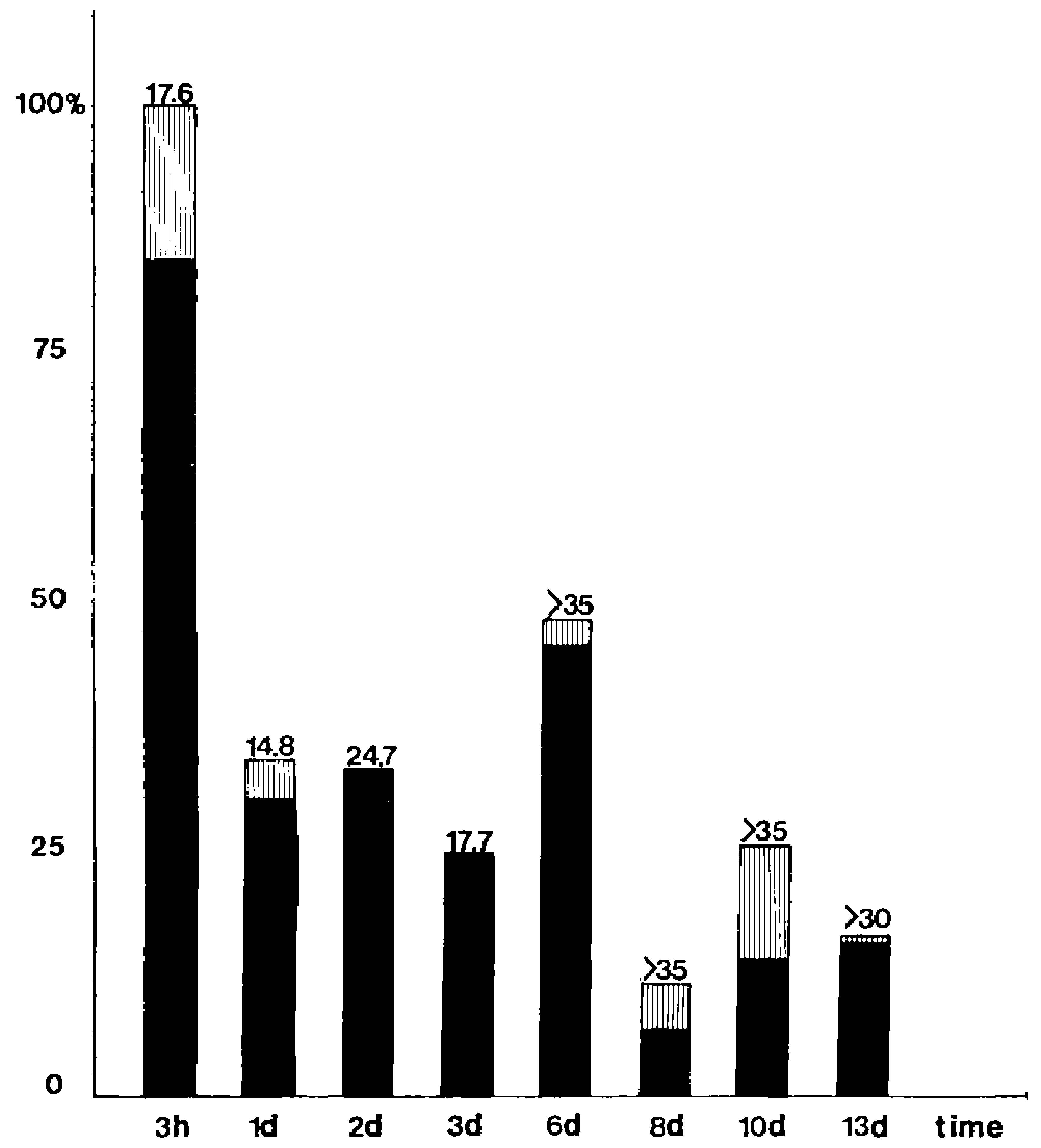

Fig. 3 - In vitro macrophage infection with amastigote. Percent of cells with intact parasites/total cells (corrected to 100 cells at 3 hours). The number above each column is the mean number of in tact parasites per cell. Macrophages containing $\square$ no parasites; $\mathbf{m}$ intact parasites.

\section{DISCUSSION}

Numerous quantitative analyses of leishmanial growth in macrophage monolayer culture have appeared in the literature. In many of these studies cell loss from the monolayer is not even considered in assessment of changes in the total parasite population. At the other extreme, recognition of the difficulty in assessing this important parameter has totally discouraged others from attempting quantitative analyses (Chang \& Dwyer 1978; Nacy \& Diggs 1981). No ideal method exists for estimating cell loss, due to the possibility of uneven distribution of cells on the substrate. We selected the method of counting predetermined fields in order to minimize subjectivity, recognizing that at best the results obtained are approximate. However, the counts did not appear to give false 


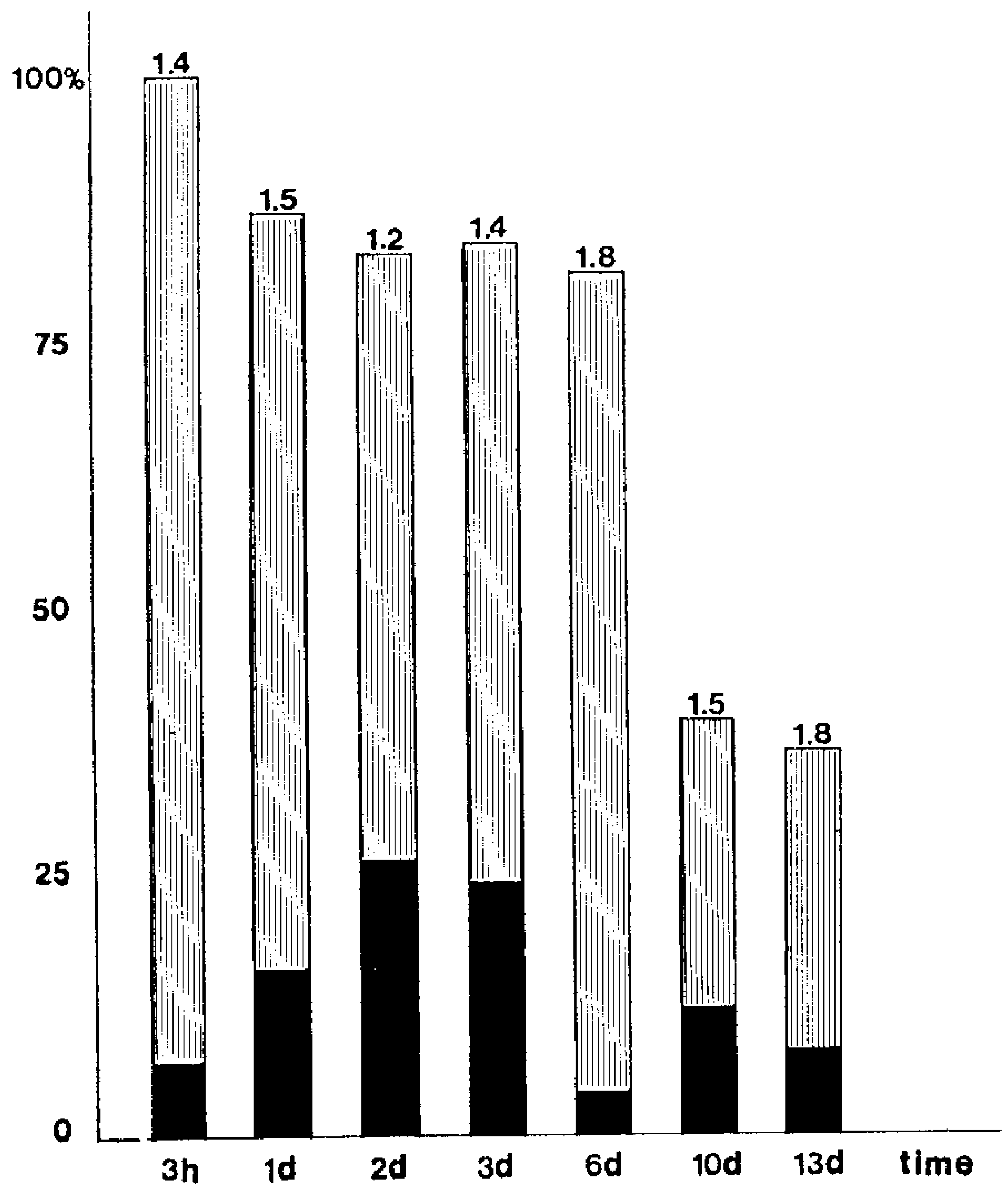

Fig. 4 - In vitro macrophage infection with fixed promastigote. Percent of cells with parasites/total cells (corrected to 100 cells at 3 hours). The number above each column is the mean number of parasites per cell. Macrophages contatining [.] no parasites; $\mathbf{E}$ fixed parasites.

impression, as judged by scanning the entire coverslips, and it was considered preferable not to ignore this factor. The cause of early cell loss in our system may have been related to toxic products in cultures in which leishmania were being destroyed (VP and AVP), as well as to intense penetration in the AM culture.

In the present study, virulent and avirulent promastigotes had similar infectivity. In contrast, Ebert et al. (1979) found reduced infectivity in vitro associated with loss of virulence in a strain of $l$. donovani; thus, long term culture may affect virulence at more than one stage of the parasitization process. In our case AVP were rapidly destroyed once within the cell. suggesting reduced ability to transform to the amastigote form and/or reduced ability to efficiently impede host destructive mechanisms during this crucial phase. In VP cultures, both destruction and multiplication occurred. The appearance of intact and degenerating forms within the same cell indicates variation within the parasite 

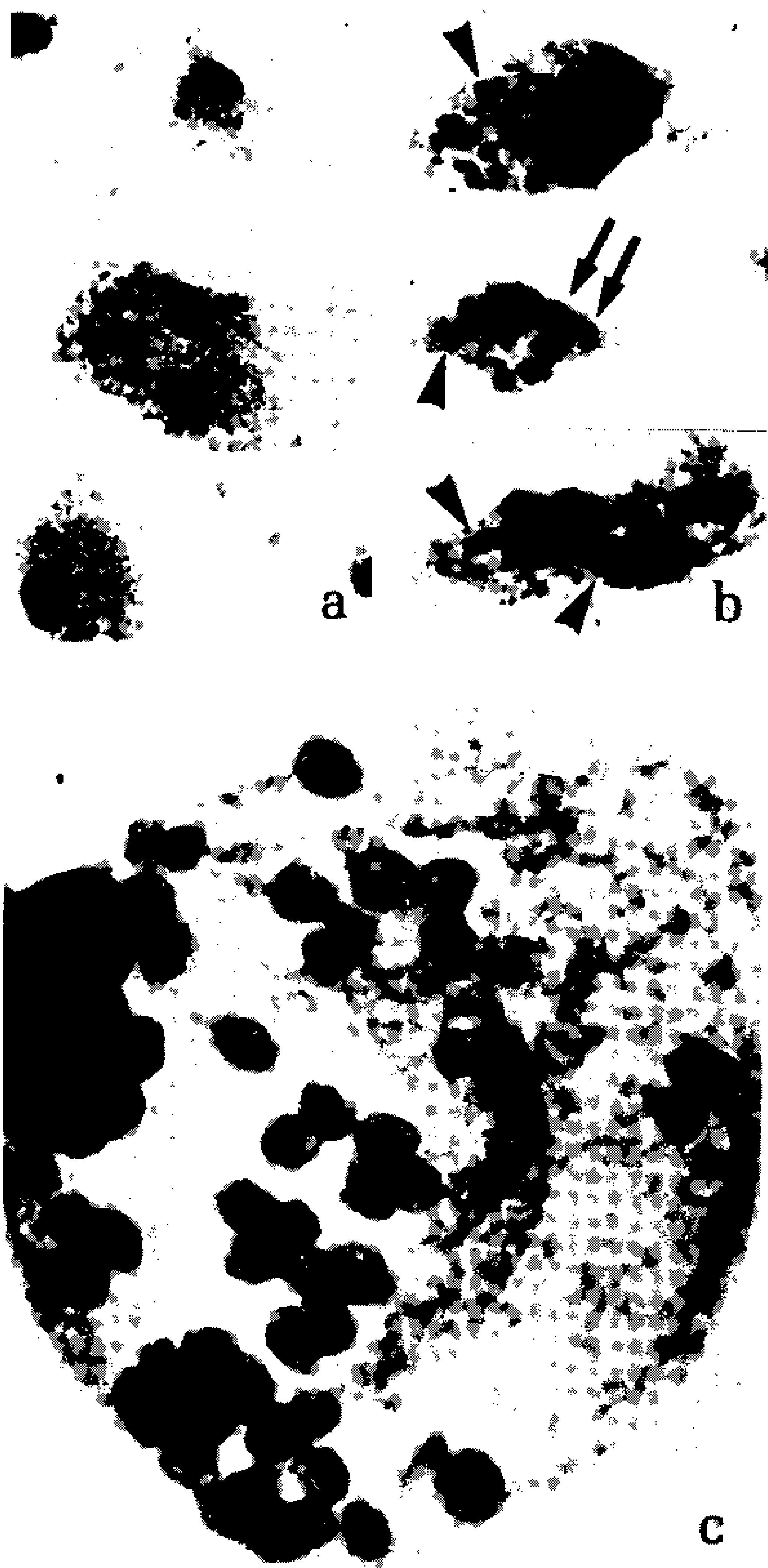

Fig. 5 - Light micrographs of normal mouse peritoneal macrophages infected with $L . m$. mexicana "strain $5 "$

a. Macrophages 24 hours after infection with AVP. Macrophages containing parasite-derived inclusion bodies (May-Grünwald-Giemsa; $x$ 800).

b. Macrophages 2 days after infection with VP. Parasitic elements represented by apparently viable amastigotes (arrows), degenerating parasites and inclusion bodies (arrowheads) are present within three host cells (May-Grünwald-Giemsa; $x$ 800).

c. Macrophages 10 days after infection with lesion-derived amastigotes. This large macrophage contains approximately 50 amastigotes, all in tact, with discernible nucleus and kinetoplast (May GrünwaldGiemsa: x 2.000). 
population in susceptibility to host destructive mechanisms. We have found no other study describing the sequence of events during intracellular destruction in promastigotederived cultures.

The host/parasite ratio used, selected to yield moderate infection with VP, resulted in superinfection with AM, clearly showing the greater infectivity of the latter. The heterogeneity of the macrophage population was incidentally demonstrated, since 16 per cent of the cells failed to take up amastigotes, while the remainder contained 7-28 forms at three hours. The differences in intensity of infection of VP and AM cultures at all time periods make it impossible to evaluate differences in susceptibility of amastigotes between them. Infection with viable amastigotes can interfere with the capacity of the macrophage to destroy other parasites which would normally not survive (Kutish \& Janovy 1981), an effect which may be cumulative with the number of amastigotes as well as with time. The degree of vacuolization of the host cell, typical of L. mexicana infection, may reflect processes involved in inactivation of host destructive capacities.

Our findings support the hypothesis that both host and parasite participate in penetration of the cell (Lewis 1974; Merino et al. 1977; Chang 1979). Motility, highest in the promastigote, is apparently secondary in favoring penetration by the living parasite to other factors which vary with the developmental stage, e.g. surface receptors (Merino et al. 1977; Zenian 1981). Low efficiency of uptake of FP may due to denaturing of receptors by fixation with 2.5 per cent gluteraldehyde, or due to lack of mobility of receptors within the membrane of the fixed organism.

Results to date show that at least three parasite-related factors influence the outcome of infection in vitro with a given strain of leishmania: ability of the parasite to enter the host cell; ability of the promastigote to successfully transform to the amastigote form (both the above being susceptible to loss in culture); and ability of the amastigote to resist destruction by the host, which may be in part a function of the number of parasites per cell. The events observed in vitro correlate well with the course of infection in vivo with VP and AVP (Grimaldi et al. 1982). Interestingly modifications of isoenzyme profiles also occur with variation in virulence, parasite stage, and tissue tropism of this strain of L. mexicana (Grimaldi et al. 1982).

\section{RESUMO}

Células peritoneais de camundongos cultivadas in vitro foram infectadas com inóculos idênticos de amastigotas (AM) e de promastigotas, respectivamente, virulentas (VP), avirulentas (AVP) e fixadas (FP) de uma mesma cepa de Leishmania m. mexicana. As monocamadas coradas com May-Grünwald-Giemsa foram examinadas em diferentes intervalos de tempo. Ao nível de $3^{\mathrm{a}}$ hora pós-infecção o número de macrófagos contendo parasitas variou entre $60,5 \%$ (VP) e $84 \%$ (AM) nas monocamadas expostas aos parasitas viáveis, comparados com $6,5 \%$ para aquelas expostas aos parasitas fixados. Entretanto, nesse tempo de interação, houve alterações degenerativas parasitárias e o número de macrófagos contendo parasitas intatos variou significantemente entre as células infectadas com AM ( $84 \%)$ e aquelas intectadas com VP $(42 \%)$ ou AVP $(40 \%)$. O número médio de parasitas intatos/macrófago também diferiu significantemente entre as células infectadas com AM e aquelas infectadas com promastigotas viáveis ou fixadas. A análise quantitativa de parasitas intatos e degenerados indicou uma multiplicação e destruição parasitária nas monocamadas infectadas com VP e sobrevivência e multiplicação parasitárias naquelas infectadas com AM. Em contraste, não houve evidência de multiplicação de parasitas nas células infectadas com AVP. Esses resultados sugerem que os eventos cruciais que determinam a evolução da infecção ocorrem durante as primeiras 24 horas da interação parasito-hospedeiro. Esses eventos são aparentemente influenciados nâo somente pela cepa do parasita ou do hospedeiro, mas também por variações ambientais induzidas em uma dada cepa parasitária. 


\section{REFERENCES}

BEHIN, R.; MAUEL, J.; BIROUM-NOERJASIN \& ROWE, D.S., 1977. Studies on cell-mediated immunity to cutaneous leishmaniasis of guinea-pigs and mice by Leishmania enriettii and Leishmania tropica. In: Colloques Internationaux du Centre de la Recherche Scientifique, No. 239 - Ecologie des Leishmanioses. Paris, Éditions dy C.N.R.S., p. 101-105.

BEHIN, R.; MAUEL, J. \& SORDAT, B., 1979. Leishmania tropica. Pathogenicity and in vitro macrophage function in strains of inbred mice. Exper. Parasitol., $48: 81-91$.

BERMAN, J.D.; DWYER, D.M. \& WYLER, D.J., 1979. Multiplication of Leishmania in human macrophages in vitro. Infect. Immun., $26: 375-379$.

BUCHM $\ddot{U L L E R}, Y$. \& MAUEL, J. 1981. Studies on the mechanisms of macrophage activation : Possible involvement of oxygen metabolites in killing of Leishmania enriettii by activated mouse macrophages. J. Reticuloendoth. Soc., $29: 181-192$.

CHANG, K.-P., 1979. Leishmania donovani: Promastigote-macrophage surface interaction in vitro. Exper. Parasitol., $48: 175-189$.

CHANG, K.-P. \& DWYER, D.M., 1978. Leishmania donovani. Hamster macrophage interaction in vitro: Cell entry, intracellular survival and multiplication of amastigotes. J. Exp. Med., 147 $: 515-530$

EBERT, $F_{\text {; }}$ BUSE, E. \& MÜHLPFORDT, H., 1979. In vitro light and electron microscope studies on different virulent promastigotes of Leishmania donovani in hamster peritoneal macrophages. Z. Parasitenkd., $59: 3141$.

GRIMALDI Jr., G.: MOMEM, H.; SOARES, M.J. \& MORIEARTY, P.L., 1982. Enzyme variation and difference in infectivity within a single strain of Leishmania mexicana mexicana. Inter. J. Parasitol., $12: 185-189$.

GUTTERIDGE, W.F.; KNOWLER, J. \& COOMBES, J.D., 1969. Growth of Trypanosoma cruzi in human heart tissue cells and effects of aminonucleoside of Puromicin, Trypacydin and Aminopterin. J. Protozool, $16: 521-525$.

HAIDARES, C.G. \& BONVENTURE. P.F., 1981. Elimination of Leishmania donovani amastigotes by activated macrophages. Infect. Immun., $33: 918-926$.

HANDMAN, E.; CEREDIG, R. \& MITCHELL, G.F., 1979. Murine cutaneous leishmaniasis: disease patterns in intact and nude mice of various genotypes and examinations of some differences between normal and infected macrophages. Aust. J. Exp. Biol. Med. Sci., 57 :9-29.

KUTISH, G.F. \& JANOVY Jr., J., 1981. Inhibition of in vitro macrophage digestion capacity by infection with Leishmania donovani (Protozoa: Kinetoplasticida). J. Parasitol., $67: 457462$.

LEWIS, D.H., 1974. Infection of tissue culture cells of low phagocy tic ability by Leishmania mexicana mexicana. Ann. Trop. Med. Parasit., 68 :327-336.

LEWIS, D.H. \& PETERS, W., 1977. The resistance of in tracellular Leishmania parasites to digestion by iysosomal enzymes. Ann. Trop. Med. Parasit., $71: 295+312$.

MAUEL, J., 1979. Leishmaniasis. In: Membrane Pathobiology of Tropical Deseases (Edited by W.H. O.). Schwabe \& Co. Basel, p. 105-129.

MERINO, F.; AJJAM, E.; HERNANDEZ, A.; DAWIDOWICZ, K. \& MERINO, E.J., 1977. In vitro infection of murine macrophage by Leishmanla brasiliensis. Mechanism of penetration. Int. Archs. Allergy appl. Immun., $55: 487495$.

MURRAY, H.W., 1981. Susceptibility of Leishmania to oxygen intermediates and killing by normal macrophages. J. Exp. Med., IS3:1302-1315. 
NACY, C.A. \& DIGGS, C.L., 1981. Intracellular replication of Leishmania tropica in mouse peritoneal macrophages: Comparison of amastigote replication in adherent and non-adherent macrophages. Infect. Immun., $34: 310-313$.

ZENIAN, A., 1981. Leishmania tropica: Biochimical aspects of promastigote attachment to macrophages in vitro. Exper. Parasitol., 51 :175-187. 